\title{
PERSEPSI MAHASISWA UNIVERSITAS PGRI PALEMBANG TERHADAP PEMBELAJARAN DARING DI PANDEMI COVID-19
}

\author{
Siti Asiyah ${ }^{1}$, Murjainah ${ }^{2}$ \\ ${ }^{1}$ Pendidikan Geografi, Universitas PGRI Palembang, Pendidikan Guru Sekolah \\ Dasar Universitas PGRI Palembang ${ }^{2}$ \\ 2murjainah18@gmail.com
}

\begin{abstract}
Abstrak: Adanya kemajuan teknologi dan informasi berpengaruh juga pada proses pembelajaran. Dunia pendidikan telah diuntungkan adanya teknologi. Seperti yang kita tahu, sejak maret 2020 WHO telah menetapkan Covid 19 sebagai pandemi global. Wabah ini memaksa kita sebagai pendidik untuk memanfaatkan teknologi dengan baik untuk pembelajaran. Meskipun idealnya pembelajaran dilakukan dengan tatap muka secara langsung, di tengah pandemic ini mengharuskan pendidik tetap melaksanakan pembelajaran secara daring. Pembelajaran daring merupakan pembelajaran yang menggunakan jaringan internet dengan aksesibilitas, konektivitas, fleksibilitas, dan kemampuan untuk memunculkan berbagai jenis interaksi pembelajaran. Penelitian ini bertujuan untuk mendeskripsikan persepsi mahasiswa Universitas PGRI Palembang terhadap pembelajaran daring. Penelitian ini dilakukan dengan menggunakan metode deskriptif kualitatif. Sampel yang digunakan dalam penelitian ini adalah cluster random sampling yang berjumlah 336 yang terdiri dari mahasiswa dari berbagai fakultas di lingkungan universitas PGRI Palembang. Data yang terkumpul dalam penelitian ini selanjutnya dilakukan analisis persentase yang berasal dari pengumpulan data angket secara online. Secara keseluruhan berdasarkan hasil analisis menunjukkan bahwa 86,9\% mahasiswa universitas PGRI Palembang sangat setuju terhadap pembelajaran daring yang dilaksanakan di tengah pandemic COVID19. Meskipun begitu, temuan utama terutama sinyal internet menjadi kendala bagi mahasiswa maupun pendidik dalam pelaksanaan pembelajaran daring walaupun baik mahasiswa maupun pendidik/dosen memiliki fasilitas teknologi pembelajaran yang mendukung pembelajaran daring, seperti handphone, laptop, paket data internet.
\end{abstract}

Kata Kunci: Persepsi, Pembelajaran Daring, Pandemi Covid-19

\begin{abstract}
The progress of technology and information also affects the learning process. The world of education has benefited from technology. As we know, since March 2020 WHO has declared Covid-19 as a global pandemic. This epidemic forces us as educators to make good use of technology for learning. Although ideally learning is done face-to-face, in the midst of this pandemic, it requires educators to carry out online learning. Online learning is learning that uses internet networks with accessibility, connectivity, flexibility, and the ability to generate various types of learning interactions. This study aims to describe the perceptions of PGRI Palembang University students towards online learning. This research was conducted using a qualitative descriptive method. The sample used in this study was 336 clusters of random sampling consisting of students from various faculties in the PGRI Palembang University. The data collected in this study then carried out a percentage analysis that came from the online questionnaire data collection. Overall, based on the results of the analysis, it shows that 86.9\% of PGRI Palembang University students strongly agree with online learning being carried out in the midst of the Covid-19 pandemic. Even so, the main finding, especially internet connection, is an obstacle for students and educators in the implementation of online learning even though both students and educators/ lecturers have learning technology facilities that support online learning, such as cellphones, laptops, internet data packages.
\end{abstract}

Keywords: Perception, Online Learning, Covid-19 Pandemic

\section{PENDAHULUAN}

Era Industri 4.0 merupakan era dimana pemanfaatan teknologi sangat pesat. Teknologi memiliki peran penting dalam dunia pendidikan baik admnistrasi maupun proses pembelajaran. Dalam proses pembelajaran, penggunaan teknologi menjadi sarana bagi pendidik dalam mentransformasikan pengetahuan (Murjainah, Aryaningrum dan Arisman, 2019). Sudah banyak institusi pendidikan menggunakan teknologi ke dalam pembelajaran sebab memberikan kemudahan dan kepraktisan bagi penggunanya. Pendidik maupun peserta didik dapat dengan mudah mengakses berbagai informasi yang dapat mereka manfaatkan untuk berbagi informasi ataupun pengetahuan. Keberhasilan penggunaan teknologi, TIK, dipengaruhi oleh beberapa faktor, yaitu faktor eksternal, kegunaan, kemudahan penggunaan, sikap dalam menggunakan, penggunaan dengan 
baik, dan sistem yang digunakan. Faktor-faktor tersebut sangat mempengaruhi keberhasilan penggunaan suatu teknologi (Ariyanto, dkk, 2010).

Hal yang sama dengan Universitas PGRI Palembang yang juga tak luput dari memanfaatkan teknologi baik untuk administrasi, pelayanan, maupun untuk pembelajaran di kelas. Universitas PGRI Palembang merupakan universitas yang dikenal dengan sebutan cyber university pada semester ganjil tahun pembelajaran 2019/2020 sudah diwajibkan menerapkan blended learning ke dalam pembelajaran bagi seluruh fakultasnya. Dalam pelaksanaan pembelajaran ini, universitas mengembangkan e-learning berbasis sistem informasi (SISFO) akademik yang terintegrasikan dengan pembelajaran. Pihak universitas membebankan pembelajaran dengan sistem offline dan online dengan perbandingan 50:50 tatap muka. Bahkan, sebelumnya program studi Pendidikan Geografi Fakultas Keguruan dan Ilmu Pendidikan, model blended learning ini sudah diterapkan beberapa semester yang lalu dengan menggunakan platform yang berbeda, yaitu Edmodo. Untuk pelaksanaannya, pembelajaran Blended Learning saat ini tidak menemukan kendala berarti dalam penerapannya, sebab mahasiswa telah mendapatkan stimulus pada pembelajaran di semester-semester sebelumnya. Namun, terjadi sebaliknya saat diterapkan di Program Studi yang lain seperti program studi Pendidikan Guru Sekolah Dasar (PGSD), ketika pelaksanaannya mereka banyak menemukan kendala seperti jaringan internet yang lambat, gagap teknologi sehingga seringkali bertanya menggunakan platform pembelajaran yang disediakan oleh universitas. Mereka beranggapan pembelajaran online me-ribet-kan pengguna dan tidak menguntungkan. Tetapi, sebaliknya pada mahasiswa yang lain merespon secara positif ketika blended learning dilaksanakan.

Terlebih lagi, di tengah pandemic covid 19 yang terjadi saat ini mengharuskan dosen melaksanakan pembelajaran dari rumah dan belajar dari rumah dengan melaksanakan pembelajaran secara daring sebagai upaya memutus mata rantai penyebaran Covid 19. Moore, Dickson, \& Galyen, (2011) mengungkapkan bahwa pembelajaran daring merupakan pembelajaran yang menggunakan jaringan internet dengan aksesibilitas, konektivitas, fleksibilitas, dan kemampuan untuk memunculkan berbagai jenis interaksi pembelajaran. Lebih lanjut, dalam pelaksanaan pembelajaran daring membutuhkan adanya fasilitas sebagai penunjang, yaitu seperti smartphone, laptop, ataupun tablet yang dapat digunakan untuk mengakses informasi dimanapun dan kapanpun (Gikas \& Grant; Handarini \& Wulandari, 2020).

Penelitian Jusmawati, Satriawati, \& Sabillah, (2020) pengaruh pembelajaran berbasis daring terhadap minat belajar matematika mahasiswa Prodi PGSD Universitas Megarezky menunjukkan bahwa pembelajaran daring berpengaruh terhadap minat belajar siswa dengan kategori baik. Meskipun penelitianpenelitian sebelumnya secara positif telah memberikan pengaruh yang signifikan kepada penggunanya. Namun, masih banyak juga mahasiswa yang merespon bahwa pembelajaran daring lebih memusingkan ketimbang pembelajaran secara tatap muka. Karena itu, setelah diterapkannya daring di universitas ini, peneliti tertarik untuk melakukan penelitian mengenai persepsi mahasiswa terhadap penerapan pembelajaran daring di civitas Universitas PGRI Palembang dengan harapan dapat menjaring persepsi mahasiswa dan menentukan kebijakan lanjutan dalam penerapan pembelajaran daring.

\section{METODE PENELITIAN}

Penelitian ini menggunakan metode deskriptif kualitatif. Penelitian ini bertujuan untuk menggambarkan atau mendeskripsikan secara holistik berdasarkan temuan, fakta dan realitas sosial di lapangan. Metode ini menggunakan pendekatan deskriptif kualitatif, karena dalam penelitian ini mengungkap fenomena realitas sosial yang terjadi di lapangan terutama persepsi mahasiswa dalam pembelajaran daring, fasilitas, pemanfaatan teknologi, temuan dan kendala-kendala dalam penerapannya. Pengumpulan data dilakukan dengan menggunakan angket online. Pengumpulan ini dilakukan sebab kondisi yang memungkinkan untuk menggunakan angket online yang diberikan kepada mahasiswa Universitas PGRI Palembang selama pelaksanaan pembelajaran daring di Pandemi Covid-19.

Pemberian angket diberikan kepada mahasiswa secara online yakni mahasiswa yang mengikuti perkuliahan di semester ganjil 20202021 dari berbagai program studi dan fakultas di Universitas PGRI Palembang dengan jumlah 336 mahasiswa di lingkungan universitas PGRI 
Palembang. Setelah angket terkumpul selanjutnya dilakukan reduksi yang bertujuan untuk mengkolektifkan mahasiswa berdasarkan fakultas dan memilah isian angket yang tidak sesuai dengan intruksi agar memudahkan peneliti saat melakukan analisis. Berdasarkan temuan saat mereduksi data terdapat 10 isian angket yang dijawab secara asal oleh mahasiswa dilihat dari pengisian nama, nama dosen pengampu dan isian pernyataan angket yang dijawab secara sama dari pernyataan satu hingga pernyataan akhir. Setelah dilakukan reduksi selanjutnya dilakukan analisis.

Isian angket mengenai pembelajaran, terdiri dari tiga poin utama dalam bahasan ini yaitu dimulai dari kegiatan pembuka, kegiatan inti hingga kegiatan penutup.Berdasarkan hasil analisis angket yang dilakukan secara persentase dengan menggunakan excel menunjukkan bahwa $86,9 \%$ persepsi mahasiswa universitas PGRI Palembang sangat setuju terhadap pembelajaran daring yang dilaksanakan di tengah pandemic COVID19. Meskipun begitu, temuan utama terutama sinyal internet dan listrik menjadi kendala bagi mahasiswa maupun pendidik dalam pelaksanaan pembelajaran daring walaupun baik mahasiswa maupun pendidik/ dosen memiliki fasilitas teknologi pembelajaran yang mendukung pembelajaran daring, seperti handphone, laptop, paket data internet.

\section{HASIL DAN PEMBAHASAN}

Universitas PGRI Palembang menjargon-kan cyber campus dimana pelaksanaan pembelajaran di lakukan secara blended learning. Kampus ini di mulai awal tahun 2020 telah meningkatkan teknologi pembelajaran terutama internet dan mengembangkan elearning. Dalam pelaksanaannya dilakukan secara blended learning, yakni menggabungkan pembelajaran tatap muka dan online. Namun, terjadinya pandemi covid saat ini mengharuskan pembelajaran dilakukan dari rumah, learning from home-study from home sehingga aktivitas pembelajaran dilakukan secara daring (dalam jaringan) dengan menerapkan pembelajaran online. Pembelajaran daring atau pembelajaran jarak jauh memiliki keleluasaan waktu belajar, dapat belajar kapanpun dan dimanapun. Mahasiswa dapat berinteraksi menggunakan beberapa aplikasi seperti classroom, video converence, telepon atau live chat, zoom maupun melalui whatsapp group (Jusmawati, Satriawati, \& Sabillah, 2020) .
Hasil tersebut, ditunjukkan pula dengan hasil perhitungan angket mengenai platform yang digunakan untuk pembelajaran dimana pelaksanaan pembelajaran daring dilakukan dengan memanfaatkan berbagai platform pembelajaran dan media social untuk pembelajaran daring, diantaranya google formulir, google translate, quizizz, blog, Edmodo, FB, IG, Whatsap, Google Classroom, Youtube, Zoom, Google meet, E-learning Universitas PGRI Palembang. Platform yang paling banyak digunakan untuk pembelajaran daring adalah google classroom dan whatsap"Untuk lebih jelasnya dapat dilihat pada tabel 1.

Tabel 1. Platrform Pembelajaran yang Sering Digunakan

\begin{tabular}{lc}
\hline \multicolumn{1}{c}{ Platform } & Frekuensi \\
\hline Google Classroom & 204 \\
\hline Edmodo & 3 \\
\hline E Learning PGRI & 157 \\
\hline Google Formulir & 70 \\
\hline Zoom & 186 \\
\hline Google Meet & 87 \\
\hline Quipper & 5 \\
\hline Quizizz & 30 \\
\hline IG & 16 \\
\hline FB & 13 \\
\hline Youtube & 11 \\
\hline WA & 253 \\
\hline Google Translate & 10 \\
\hline Blog & 35 \\
\hline
\end{tabular}

\section{Diagram Platform Pembelajaran}

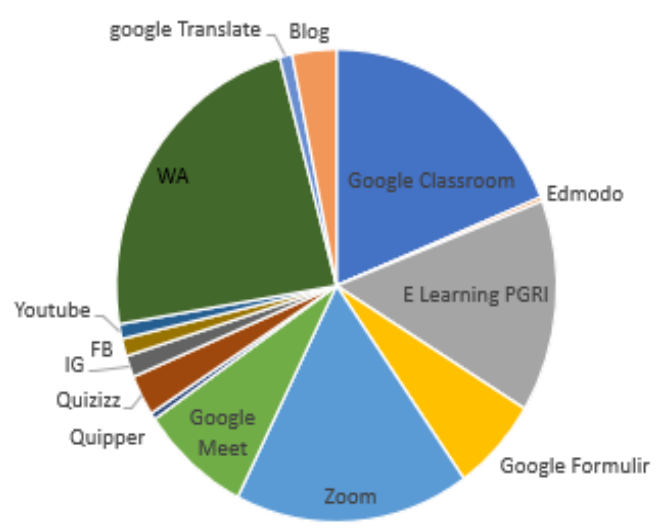

Gambar 1. Diagram Platform Pembelajaran yang Sering Digunakan

Kemudian, kegiatan pembelajaran yang dimulai dengan kegiatan pembuka yakni, dimulai dengan salam pembuka, penyampaian 
tujuan pembelajaran, melakukan apersepsi menunjukkan bahwa pada kegiatan ini mahasiswa sangat setuju pelaksanaan pembelajaran daring dilakukan dengan baik oleh dosen pengampu, dan membuat mahasiswa senang dan antusias melakukan pembelajaran daring dengan menggunakan berbagai platform pembelajaran dengan persentase $88,7 \%$. Lalu, pada kegiatan inti saat berlangsungnya pembelajaran daring yang dilakukan diantaranya, dosen menyampaikan materi, memberikan kesempatan bertanya untuk mahasiswa membuat mahasiswa senang dan antusias belajar dengan menggunakan berbagai platform pembelajaran yang menunjukkan bahwa 88,3\% mahasiswa sangat setuju terhadap pembelajaran daring. Selanjutnya, pada kegiatan penutup pembelajaran daring sebesar $84,7 \%$ mahasiswa setuju terhadap pembelajaran daring, yang terdiri dari kegiatan menyimpulkan pembelajaran, mendiskusikan masalah yang dihadapi mahasiswa dalam pembelajaran daring, memberikan tugas, memberikan penilaian dengan baik sehingga membuat mahasiswa senang dan antusias belajar saat pembelajaran daring dengan menggunakan berbagai platform pembelajaran.

Sobron, Bayu, Rani, \& Meidawati, (2019) mengungkapkan bahwa pembelajaran daring juga sangat efektif bagi siswa karena bisa berlatih dengan adanya umpan balik terkait menggabungkan kolaborasi kegiatan dengan belajar mandiri, dan personalisasi pembelajaran berdasarkan kebutuhan siswa yang menggunakan simulasi dan permainan. Pembelajaran berbasis Daring dibangun melalui beberapa prinsip yang berperan untuk menentukan keberhasilan proses pembelajaran. Hal ini membuat pembelajaran berbasis Daring menjadi efektif yang dasarnya bergantung dari pandangan pemegang kepentingan. Menurut Rusman; Sobron, Bayu, Rani, \& Meidawati, (2019) setidaknya harus ada prinsip utama dalam pembelajaran berbasis Daring Learning di antaranya; Interaksi dan ketergunaan.

Interaksi berarti kapasitas komunikasi dengan orang lain yang tertarik pada topik yang sama atau menggunakan pembelajaran berbasis Daring Learning. Dalam lingkungan belajar, interaksi berarti kapasistas berbicara baik antar peserta maupun antara peserta dengan instruktur. Interaksi membedakan antara pembelajaran berbasis Daring Learning dengan pembelajaran berbasis komputer (Computer-Based Instruction). Hal ini berarti bahwa mereka yang terlibat dalam pembelajaran berbasis Daring Learning tidak berkomunikasi dengan mesin, melainkan dengan orang lain (baik peserta maupun tutor) yang kemungkinan tidak berada pada lokasi dengan waktu yang sama. Interaksi tidak hanya menyediakan hubungan antar manusia, tetapi menyediakan keterhubungan isi, dimana setiap orang dapat membantu antara satu dengan yang lain untuk memahami isi materi dengan berkomunikasi. Hal tersebut menciptakan lapisan belajar terdalam yang tidak bisa diciptakan oleh pengembangan media.

Ketergunaan yang dimaksudkan adalah bagaimana bisa pembelajaran yang berbasis Daring Learning diaktualisasikan. Terdapat dua elemen penting dalam prinsip ketergunaan, yaitu konsistensi dan kesederhanaan. Intinya adalah bagaimana perkembangan pembelajaran berbasis Daring Learning ini menciptakan lingkungan belajar yang konsisten dan sederhana, sehingga siswa tidak mengalami kesulitan baik dalam proses pembelajaran maupun navigasi konten (materi dan aktivitas belajar lain)

Dengan demikian, dapat disimpulkan bahwa persepsi mahasiswa Universitas PGRI Palembang $86,9 \%$ sangat setuju terhadap pembelajaran daring. Meskipun begitu, pembelajaran tatap muka di kelas masih tetap disukai oleh mahasiswa. Ini ditunjukkan pada hasil perhitungan angket sebesar 64,4\% mahasiswa lebih senang dan antusias terhadap pembelajaran yang dilaksanakan melalui platform pembelajaran dibandingkan tatap muka di kelas. Hasil analisis ini paling rendah dibandingkan dengan hasil analisis angket lain dalam kegiatan pembelajaran. Artinya pembelajaran yang dilakukan secara tatap muka di kelas tetap disukai oleh mahasiswa. Berdasarkan hasil penelitian Mustakim, (2020) menunjukkan bahwa sebagian peserta didik yang menyukai pembelajaran menggunakan daring yakni sebesar $26,7 \%$, dan yang menyukai model pembelajaran blended (perpaduan tatap muka dengan daring) sebesar 26,7\%, serta sebagian besar peserta didik menyatakan menyukai pembelajaran dengan tatap muka yakni sebesar $46,6 \%$, Meskipun banyak kemudahan yang diberikan pembelajaran daring melalui internet, namun hasil penelitian ini menunjukkan peserta didik lebih menyukai pembelajaran tatap muka. Berdasarkan wawancara dengan psikolog pendidikan, Eva Maizarra Puspita Dewi, dikemukakan bahwa ada tiga reaksi perilaku individu ketika diperhadapkan dengan bahaya, 
pertama dia akan menolak kenyataan. Selanjutnya, dia akan tawar menawar, dan terakhir dia akan menerima.

\section{PENUTUP}

Ada beberapa indikator dalam mendeksripsikan persepsi mahasiswa terhadap pembelajaran online. Indikator tersebut antara lain, ketersediaan/kelengkapan fasilitas online, kemudahan akses, dan kegiatan pembelajaran.

Ketersediaan atau kelengkapan fasilitas terdiri dari fasilitas online, jaringan listrik, jaringan internet ditempat tinggal, handphone, laptop, dan jaringan listrik. Sebanyak 77,49\% mahasiswa FKIP, 84,62\% mahasiswa Fakultas Teknik, 90,24\% mahasiswa Fakultas Ekonomi, 100\% mahasiswa FMIPA, dan 50\% mahasiswa Fakultas Perikanan menjawab tersedia fasilitas online untuk belajar. Sebanyak 67,90\% mahasiswa FKIP, 53,8\% mahasiswa Fakultas Teknik, 70,73 \% mahasiswa Fakultas Ekonomi, $83,30 \%$ mahasiswa FMIPA, dan $16,67 \%$ mahasiswa Fakultas Perikanan menjawab tersedia jaringan listrik. Sebanyak 48,71\% mahasiswa FKIP, 15,38\% mahasiswa Fakultas Teknik, 58,54\% mahasiswa Fakultas Ekonomi, 83,30\% mahasiswa FMIPA, dan 33,33\% mahasiswa Fakultas Perikanan menjawab tersedia jaringan internet ditempat tinggal.

1. Sebanyak $90,04 \%$ mahasiswa FKIP, $92,31 \%$ mahasiswa Fakultas Teknik, 97,56\% mahasiswa Fakultas Ekonomi, 83,30\% mahasiswa FMIPA, dan 66,67\% mahasiswa Fakultas Perikanan menjawab tersedia fasilitas handphone.

2. Sebanyak $61,25 \%$ mahasiswa FKIP, $69,23 \%$ mahasiswa Fakultas Teknik, 48,78\% mahasiswa Fakultas Ekonomi, 83,30\% mahasiswa FMIPA, dan $50 \%$ mahasiswa Fakultas Perikanan menjawab tersedia fasilitas laptop.

3. Sebanyak 79,70\% mahasiswa FKIP, $69,23 \%$ mahasiswa Fakultas Teknik, 87,80\% mahasiswa Fakultas Ekonomi, 83,30\% mahasiswa FMIPA, dan 83,30\% mahasiswa Fakultas Perikanan memiliki akses informasi dari kampus. Sebanyak 56,83\% mahasiswa FKIP, 23,08\% mahasiswa Fakultas Teknik, $51,22 \%$ mahasiswa Fakultas Ekonomi, $33,30 \%$ mahasiswa FMIPA, dan 50\% mahasiswa Fakultas Perikanan memiliki kemudahan akses internet.

4. Sebanyak $81,18 \%$ mahasiswa FKIP, $69,23 \%$ mahasiswa Fakultas Teknik, 90,24\% mahasiswa Fakultas Ekonomi, 83,30\% mahasiswa FMIPA, dan 83,33\% mahasiswa Fakultas Perikanan menjawab pembelajaran dari dosen mudah diakses dengan baik.

Pada kegiatan pembuka pada Pembelajaran Daring sebanyak 88,4 mahasiswa Universitas PGRI Palembang sangat setuju bahwa dosen membuka kegiatan pembelajaran dengan sangat baik. Sebanyak $88 \%$ mahasiswa menyatakan pada kegiatan inti dosen telah menyampaikan pembelajaran dengan baik. Begitu juga pada kegiatan penutup, sebanyak 84,3 mahasiswa menyatakan dosen menutup kegiatan pembelajaran dengan baik

\section{DAFTAR PUSTAKA}

Arianto,F., Susarno, L.H., Dewi, Utari dan Safitri A.F. (2020). Model Penerimaan dan Pemanfaatan Teknologi: E-Learning di Perguruan Tinggi. Jurnal Kwangsan: Online ISSN: 2622-4283, Print ISSN: 2338-9184 Vol.08/10 Juli 2020. 112-121.

Ferdiana, S. (2020). Persepsi Mahasiswa tentang Penggunaan Media Daring pada Program Studi S1 Ilmu Gizi Sekolah Tinggi Ilmu Kesehatan Surabaya Selama Masa Pandemi COVID 19. Indonesian Journal of Science Learning IJSL 1 (1) (2020) 0512/ ISSN: 0000-0000, 5-12.

Handarini, O. I., \& Wulandari, S. S. (2020). Pembelajaran Daring Sebagai Upaya Study From Home (SFH) Selama Pandemi Covid 19. Jurnal Pendidikan Administrasi Perkantoran (JPAP) Vol 8, Nomor 3, 496-503.

Jusmawati, J., Satriawati, S., \& Sabillah, B. M. (2020). Pengaruh Pembelajaran berbasis Daring Terhadap Minat belajar Mahasiswa PGSD UNIMERS Pada Mata Kuliah Pendidikan Matematika. Jurnal Kajian Pendidikan Dasar Volume 5. Nomor 2 Juli , 106-111.

Moore JL, Dickson-Deane C, Galyen K. 2011, E-Learning, online learning, and distance learning environments: Are they the same, The Internet and Higher Education.;14(2):129-35.

Murjainah, Aryaningrum, K., \& Arisman. (2019). Upaya Meningatkan Softskill Disiplin Melalui Penggunaan Edmodo dengan Metode Blended Learning. Jurnal Teknologi Pendidikan, Vol.12 No.2, Oktober 2019, E-ISSN:2407-7437, 169177.

Mustakim. (2020). Efektivitas Pembelajaran Daring Menggunakan Media Online 
Jurnal Teknologi Pendidikan, Vol. 14, No. 2, Oktober 2021, e-ISSN: 2407-7437

Selama Pandemi COVID 19 pada Mata Pelajaran Matematika. Al asma: Journal of Islamic Education, Vol. 2, No. 1, May, $1-12$.

Sobron, A. N., Bayu, Rani, \& Meidawati, S. (2019). PERSEPSI SISWA DALAM STUDI PENGARUH DARING LEARNING TERHADAP.

SCAFFOLDING: Jurnal Pendidikan Islam dan Multikulturalisme, Vol. 1, No. 2, Desember , 30-38 